\title{
The Preservation, Renewal and Cultural Remolding of Industrial Heritage under the Background of Urban Double Construction: A Case Study of Jinling Shipyard in Nanjing
}

\author{
Yujie Yao', Mingming Xiang2* \\ ${ }^{1}$ School of Architecture and Civil Engineering, Southwest University of Science and Technology, Mianyang, China \\ ${ }^{2}$ School of Architecture, Southwest Minzu University, Chengdu, China \\ Email: 1254955199@qq.com, ^mingmingxiang@hotmail.com
}

How to cite this paper: Yao, Y. J., \& Xiang, M. M. (2021). The Preservation, Renewal and Cultural Remolding of Industrial Heritage under the Background of Urban Double Construction: A Case Study of Jinling Shipyard in Nanjing. Open Journal of Social Sciences, 9, 243-253.

https://doi.org/10.4236/jss.2021.99018

Received: August 15, 2021

Accepted: September 10, 2021

Published: September 13, 2021

Copyright $\odot 2021$ by author(s) and Scientific Research Publishing Inc. This work is licensed under the Creative Commons Attribution International License (CC BY 4.0).

http://creativecommons.org/licenses/by/4.0/

\begin{abstract}
"Urban renovation and ecological restoration" is an effective means to control "Urban disease", improve the living environment and change the urban development mode. This article from the perspective of "Urban renovation and ecological restoration" by Nanjing Jinling shipyard development problems, from the ecological restoration, cultural remodeling and function transformation and other respects, discusses the current Jinling shipyard area between industrial heritage protection and cultural inheritance update problem. Using field research, literature reading, case study and other methods, and put forward corresponding planning strategies and suggestions. Integrate the needs of people's livelihood with urban industrial memory to realize the maximum protection, renewal and utilization of industrial heritage areas.
\end{abstract}

\section{Keywords}

Urban Renovation and Ecological Restoration, Industrial Heritage, Nanjing Jinling Shipyard

\section{Introduction}

In the 40 years after China's reform and opening up, rapid urbanization has played an irreplaceable role in economic and social development, changing China's urban and rural appearance and promoting social development. At the same time, there are also some prominent problems (Gan \& Wang, 2018). For exam- 
ple, the annual urban planning conference held in Hangzhou in 2018 pointed out that "the problem of large-scale demolition and construction is prominent, the characteristics are missing, and the inheritance is worrying" (Zhang, 2018). Among them, large-scale demolition and construction include a large number of historical blocks and historical ancient buildings, among which Industrial Relics bear the brunt.

Under the background of high-quality requirements in the new era, in the guidance on strengthening urban repair of ecological restoration issued by the Ministry of housing and urban rural development in 2015 (replaced by the guidance below), it is proposed that "double repair" refers to ecological restoration and urban repair. Among them, ecological restoration aims to restore the damaged mountains, rivers and vegetation step by step, with the focus on restoring the self restoration effect of urban ecosystem through a series of measures; Urban repair focuses on improving the efficiency of urban public services, improving municipal infrastructure conditions, excavating and maintaining urban history and social networks, so as to systematically repair, make up and improve the urban functional system and its bearing space (Rong \& Cai, 2019). In the "double repair", the guiding opinions repeatedly put forward the protection and use of industrial heritage, such as "enhancing the protection, inheritance and effective utilization of cultural heritage, protecting ancient relics, ancient buildings and modern historical buildings, better continuing the context and displaying the city style" (Yang, 2017). Therefore, how to use it on the basis of protecting industrial heritage to make it better continue culture, how to start with urban repair and ecological restoration, systematically solve the loss of urban style and historical context in the process of urban park heritage development and renewal, and promote the comprehensive, reasonable renewal and orderly development of industrial heritage and its surroundings are the main problems discussed in this paper. In view of this, this paper studies the Jinling shipyard area in Qiaodong area of Nanjing, puts forward the corresponding planning strategies, and studies the protection, renewal and cultural reconstruction of industrial heritage.

\section{Concept and Theoretical Basis}

\subsection{Related Concepts}

\subsubsection{Industrial Heritage}

Industrial heritage is composed of historical relics containing industrial culture, including many buildings and structures, production and processing equipment, factories, mining areas, warehouses and other places and facilities closely related to industrial production (Wang, 2017).

\subsubsection{Renovation and Restoration}

"Renovation and restoration" is to complete the transformation of urban development mode and governance mode through urban repair and ecological restoration. Among them, ecological restoration refers to the management and restoration of ecological elements such as mountains, water bodies, green space sys- 
tem and abandoned land in the city on the premise of systematic analysis of urban ecological security pattern, so as to improve the overall ecological pattern and ecological environment of the city. Urban repair refers to the use of the overall urban design method to repair and update urban functions, improve urban infrastructure, travel conditions, repair urban space environment, history and culture, urban style, and improve environmental quality and urban vitality (Wang, 2017). Its central meaning is the planning strategy and method for urban development in the transition period, focusing on the maintenance of ecosystem and the improvement of urban life quality (Shi et al., 2017).

\subsubsection{Industrial Heritage Conservation}

From the Charter of Athens in 1993 to the Machu Picchu Chapter in 2003, foreign experience on the protection of industrial heritage has gradually matured, and the idea of industrial heritage protection is gradually attracting the attention of countries all over the world (Table $1 \&$ Table 2).

In conclusion, to the extent of industrial heritage protection abroad, methods etc are in constant progress, from a single building to the overall protection, the protection of industrial heritage content increasing. Compared with China, the protection of industrial heritage started relatively late, and many studies are based on foreign interpretation.

Table 1. List of relevant institutions and international documents on industrial heritage conservation (Author summary).

\begin{tabular}{|c|c|c|c|}
\hline Name of institution & The relevant documents & Time and place & The main content \\
\hline \multirow{2}{*}{$\begin{array}{l}\text { The International } \\
\text { Congress of Modern } \\
\text { Architecture (CIAM) }\end{array}$} & "Charter of Athens" & 1933 & $\begin{array}{l}\text { Ancient buildings with historical value and representing } \\
\text { a certain period are of great educational significance } \\
\text { and should be properly preserved without damage. }\end{array}$ \\
\hline & "Machu Picchu Charter" & $\begin{array}{l}1977 \\
\text { Lima, Peru }\end{array}$ & $\begin{array}{l}\text { The protection, restoration and reuse of existing historical } \\
\text { sites and ancient buildings must be combined with the urban } \\
\text { construction process to ensure that cultural relics have } \\
\text { economic significance and vitality. }\end{array}$ \\
\hline \multirow{2}{*}{ UNESCO } & "The Venice Charter" & $\begin{array}{c}1964 \\
\text { Venice, Italy }\end{array}$ & $\begin{array}{l}\text { The focus and direction of modern conservation movement } \\
\text { has changed from cultural relics to architecture and region. }\end{array}$ \\
\hline & "World Heritage Convention" & $\begin{array}{l}1972 \\
\text { Paris, France }\end{array}$ & $\begin{array}{l}\text { Formulate general standards for the evaluation of } \\
\text { cultural heritage. }\end{array}$ \\
\hline $\begin{array}{l}\text { World Heritage } \\
\text { Centre (WHC) }\end{array}$ & "Operational Guidelines" & 1987 & $\begin{array}{l}\text { It clearly explains the concept, value, significance and } \\
\text { protection purpose of cultural heritage, as well as the } \\
\text { value of the Venice Charter. }\end{array}$ \\
\hline ICOMOS & "The Washington charter" & $\begin{array}{c}1987 \\
\text { Washington, DC }\end{array}$ & $\begin{array}{l}\text { The protection of historical cities and regions should } \\
\text { become an integral part of the overall policy of social and } \\
\text { economic development and be included in the urban } \\
\text { planning and management plan at the whole level. }\end{array}$ \\
\hline TICCIH & "The Nizhny Tagil Charter" & $\begin{array}{l}2003 \\
\text { Nizhni Tagil, Russia }\end{array}$ & $\begin{array}{l}\text { It records the definition and value of industrial heritage, } \\
\text { as well as the importance of identifying, registering and } \\
\text { studying industrial heritage, and puts forward guidelines } \\
\text { and serious Guiding Opinions on legislation, } \\
\text { maintenance and publicity. }\end{array}$ \\
\hline
\end{tabular}


Table 2. Comparison of theoretical research on industrial heritage protection at home and abroad (Author summary).

\begin{tabular}{|c|c|c|}
\hline View of research & The overseas study & The research in China \\
\hline $\begin{array}{l}\text { Conservation } \\
\text { and reuse of } \\
\text { industrial buildings }\end{array}$ & $\begin{array}{l}\text { Lawrence Halprin put forward the idea of "recycling" } \\
\text { in the design practice of Girardelli Square in San } \\
\text { Francisco, USA (Merkel , 2007): Museums often } \\
\text { attract the attention of many researchers in terms } \\
\text { of the maintenance of craft heritage, such as } \\
\text { Bowditch J, Hendricks J, De Corte B, etc. }\end{array}$ & $\begin{array}{l}\text { In the paper "A Study on the Reuse of Old Industrial Buildings", } \\
\text { Zhuang Jiandi discussed the ways of Reuse from the perspective } \\
\text { of sustainable development (Zhuang, 2004); In the paper } \\
\text { "Regeneration and Redevelopment of Historic Industrial } \\
\text { buildings and sites" Wang Jianguo and Rong Junqiang } \\
\text { systematically discussed the ways of Redevelopment and use } \\
\text { and the technical methods of renovation and design (Wang \& } \\
\text { Rong, 2001). }\end{array}$ \\
\hline $\begin{array}{l}\text { Post-industrial } \\
\text { landscape }\end{array}$ & $\begin{array}{l}\text { Kirsten Jane Robinson in "Exploring Urban } \\
\text { Ecosystems in the Ruhr Region of Germany: } \\
\text { Implementation Strategies" from the urban } \\
\text { ecological planning and construction of case, studies } \\
\text { the ecological strategies and Germany is currently in } \\
\text { new urban planning paradigms (Robinson \& Wang, } \\
\text { 2003); In "Between landscape architecture and land } \\
\text { art" Weilacher. U discusses the foundation book and } \\
\text { landscape design in the abandoned industrial } \\
\text { environment (Weilacher, 1999); Naill Kirkwood } \\
\text { edited "Manufactured Sites: Rethinking the } \\
\text { Post-Industrial Landscape" is a treatise on the } \\
\text { updating of abandoned land (Niall, 2003). }\end{array}$ & $\begin{array}{l}\text { In the paper "From Industrial Wasteland to Green Park" } \\
\text { Ren Jingyan discussed the rich design ideas of design aesthetics, } \\
\text { art, ecology and other related humanities in post-industrial } \\
\text { landscape design, and discussed the unique techniques used in } \\
\text { the design (Wang \& Ren, 2003); In the paper "Study of } \\
\text { Post-Industrial Landscape", He Wang mentioned the concept of } \\
\text { Industrial heritage, and proposed the idea of hierarchical } \\
\text { protection, and summarized the paradigm and ideas of Industrial } \\
\text { Landscape design (He, 2004). }\end{array}$ \\
\hline $\begin{array}{c}\text { Industrial } \\
\text { heritage tourism }\end{array}$ & $\begin{array}{l}\text { J. Arwel Rdwards. Joan Caries Liurd si Coit put } \\
\text { forward that the attraction sites of industrial } \\
\text { heritage tourism should be included in the broader } \\
\text { framework of heritage tourism and discusses the } \\
\text { system of industrial heritage sites. }\end{array}$ & $\begin{array}{l}\text { In the paper "De-industrialization and development of } \\
\text { industrial heritage tourism: the actual process and } \\
\text { development model of Ruhr in Germany", Li Leilei summarized } \\
\text { three development modes of industrial tourism (Li, 2002); } \\
\text { Wu Xiangli's "Main characters and experience of British } \\
\text { industrial tourism" starts with the operation concept and } \\
\text { summarizes the basic characteristics of the development of } \\
\text { British industrial tourism (Wu, 2002). }\end{array}$ \\
\hline $\begin{array}{l}\text { Industrial } \\
\text { Heritage } \\
\text { conservation }\end{array}$ & $\begin{array}{l}\text { Zhang Jiazhen and Cenci Jeremy analyzed the status } \\
\text { quo of Belgium's industrial heritage and its } \\
\text { protection and renewal as a cultural carrier } \\
\text { (Zhang et al., 2021). }\end{array}$ & $\begin{array}{l}\text { Shan Jixiang discussed the general survey and identification, } \\
\text { legislation and protection of industrial heritage in his } \\
\text { "Attention to Emerging Cultural Heritage-Protection } \\
\text { of Industrial Heritage" (Shan, 2007). }\end{array}$ \\
\hline Ecology & $\begin{array}{l}\text { In "Handbook of Regenerative Landscape Design" } \\
\text { Robert L. France describes the strategic measures } \\
\text { taken by experts in different fields to deal with } \\
\text { degraded landscapes, demonstrating the } \\
\text { Regenerative process of ecological landscapes } \\
\text { (France, 2010). }\end{array}$ & $\begin{array}{l}\text { In the paper "Study on Revegetation During Ecological } \\
\text { Restoration of Industrial Wasteland", Bao Zhiyi stated that } \\
\text { vegetation reconstruction is the most important task of the } \\
\text { ecosystem of Industrial heritage sites (Bao \& Chen 2004); } \\
\text { Cheng Lan in "Ecological restoration and Landscape } \\
\text { regeneration of Industrial wasteland" deals with } \\
\text { detailed steps for ecological restoration (Cheng, 2014). }\end{array}$ \\
\hline
\end{tabular}

\section{Jinling Shipyard Lot Planning Project Practice}

\subsection{Analysis on the Current Situation of Jinling Shipyard Industrial Heritage Area}

\section{Case Area Overview}

The base is located around the Guanyin Scenic spot of Nanjing Yangtze River, reaching Baochuan No.5 Road in the east, Qiaodong Street in the south, Baochuan No.2 Road in the west and the riverside in the north, covering an area of about 33 hectares (Figure 1). It is the largest shipbuilding leading enterprise under Sinotrans Limited. It is recognized as a high-tech enterprise by Jiangsu Province 


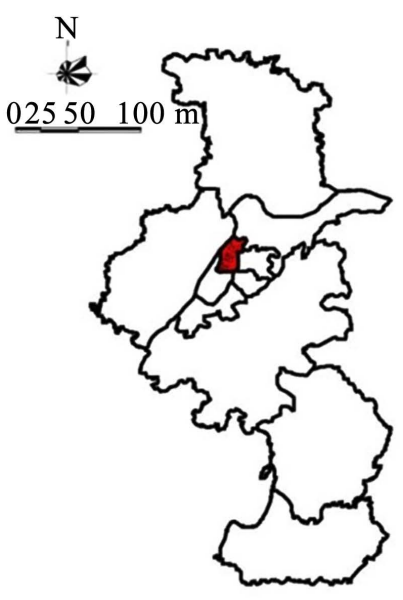

(1) Location of Gulou District

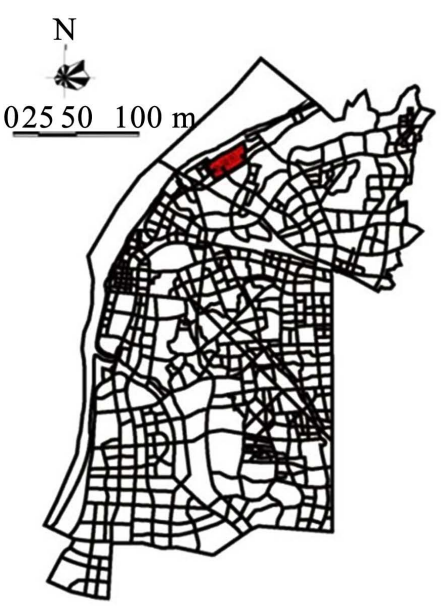

(2) The location of the base in Gulou district

Figure 1. Base on the location.

and listed as a tax declaration factory by China Customs. The spatial pattern of the factory has not changed for more than half a century, and the historical evolution is clear to follow. At present, there are a large number of structures and equipment with distinctive industrial culture in the factory. Such as freight terminals, industrial plants, transport tracks, etc. The building structure in the factory is well preserved, the shipbuilding process is clear, and the outdoor space is rich. It is located at the foot of Nanjing Yangtze River Bridge, and can form a opposite view with the bridge. It is an important part of the surrounding landscape of the Yangtze River Bridge. However, due to the long-term factory operation, the shoreline in the shipyard wharf area is damaged, the industrial pollution is serious, and the ecosystem is seriously damaged.

The location of the base and its distinctive industrial cultural heritage lay the foundation for its transformation in the process of renewal and transformation, which is a necessary road of transformation and change under the background of ecological restoration and urban repair. Therefore, how to use the good environmental resources around the base, cultural heritage, convenient transportation resources to protect the industrial heritage and cultural remodeling of the base is the part we need to focus on today.

\subsection{Site Planning Strategy of Jinling Shipyard}

Based on the comprehensive analysis of the Overall Planning of Nanjing Gulou District, the shipyard area is the continuation of binjiang business characteristic area.

In the control plan, the base belongs to the modern industrial function group, Qiaodong group, located on the riverside scenery belt, close to the urban function axis, its positioning is economic, supplemented by culture; The main purpose of the plan is to retain and explore the cultural network of Jinling Shipyard and improve the environment of the shipyard and the surrounding area. Pro- 
mote the economic, cultural and ecological development of the surrounding areas.

The site planning should combine the "framework" and "skeleton" of the "organism" of the plot. Combined with the upper, financial, urban context, ecology and other factors, to create a characteristic industrial heritage base. Therefore, the author thinks about the planning strategy of Jinling Shipyard in the following aspects:

\subsubsection{Protection and Function Transformation of Industrial Heritage}

According to the scene reconnaissance, information collection summary, found that shipyard building is built in the 1950s more original old factory building, large width, construction simple, just pure to shipbuilding factory streamline work before, whole space relationship is weak, cannot with the function of the commercial operation service, whole feels comfortable enough (Figure 2).

So the protection level, take the way of "local retention, upgrading", based on the factory building, function, quality, retention value of comprehensive consideration, key protection terminals, shipyards, main workshop space, to dismantle architecture of no value, build consistent with shipyard whole industrial style of new buildings, injected fresh energy to the base. Space will be shaped through the coordination of architectural form and style between new and old buildings; The enclosure of the building creates public open space; At the same time, the transition space between the new building and the old building is considered to coincide with the vertical corridor of the site landscape. By combining with the vertical riverside building layout, the new and old buildings are organically combined (Figure 3).

In terms of structures, the original tower cranes, gantry frames and pipelines in the shipyard are mainly retained, which combine with the surrounding environment to enhance the industrial sense, retain the characteristics of shipyard manufacturing, and fill in the main landscape for the site park. In addition, the zigzag frame left after the demolition of the old factory can also be used as a swing, and can be used as an electric rail station and a small kiosk with rain proof plates (Figure 4).

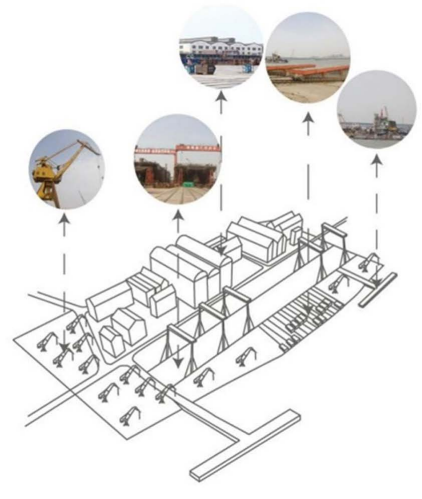

(1) Internal status of the base

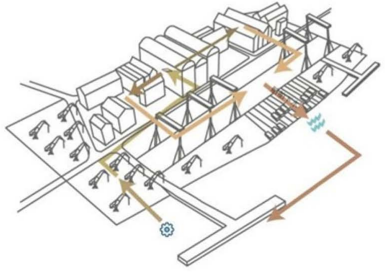

(2) Ship production line

Figure 2. Internal status of the base. 


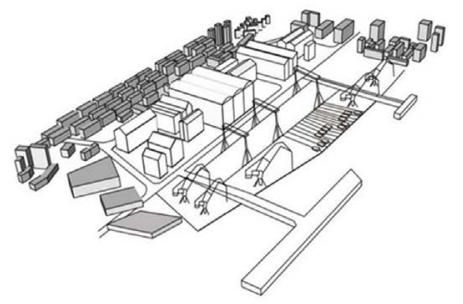

The building is large and disordered

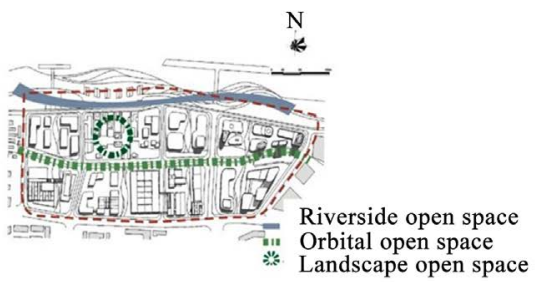

Create open space

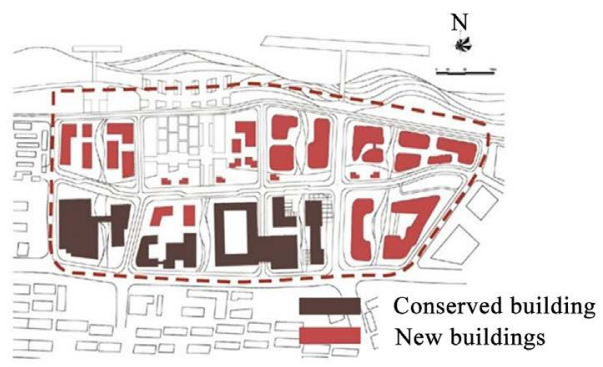

Conduct building quality evaluation and demolish part of the building

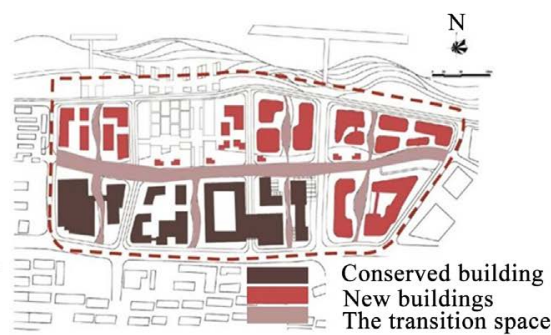

Figure 3. Conservation and renewal of the building in the site.
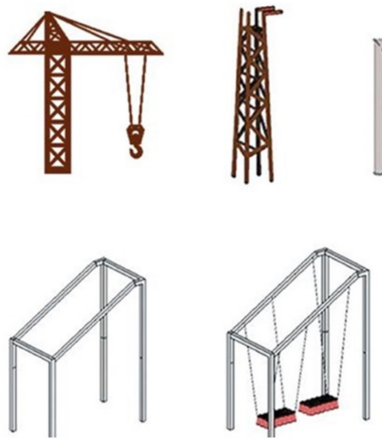

Tower crane, Longmen shelf, The pipe

Retain part of the original tower crane, gantry frame, combined with the surrounding environment, fill in the main landscape for the site park.
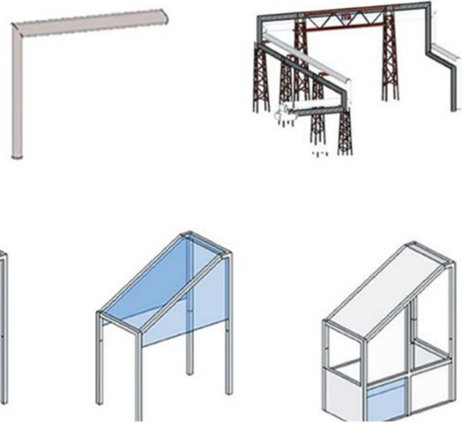

shell frame

After the demolition of the factory, there are many zigzag frames left. which can be used as swings, and can also be transformed into rail stations and snack shops.

Figure 4. Renovation of existing industrial components in the site.

\subsubsection{Ecological Restoration Strategy}

Because the shipyard has been single industrial for a long time, the shipyard area is seriously artificial, the natural coastline near the Yangtze River is destroyed, the flood control project is missing, the dust brings serious industrial pollution, and the ecosystem is seriously damaged. Therefore, two basic ways of waterfront restoration and rainwater utilization are adopted in the base to carry out ecological restoration.

The most original natural riverbank has the functions of ecological conservation, water purification and biological habitat (Lin \& Liu, 2019). However, due to the long-term wharf lightening function and flood control arrangement of the shipyard's coastline, the cement dam has been built, which destroys the water- 
front ecology and viewing function. Therefore, in the planning, the elevation of the existing waterfront site is 5 - 6 meters, and the original industrial embankment is considered to be demolished and vertical flood prevention walls are adopted to form a millennium flood prevention system. At the same time, combining with the annual change of water level, the riverside view line parallel to the shoreline is built. In addition to the plant configuration. Planting more waterfront plants can not only increase the appreciation, but also have ecological protection effect (Figure 5).

Different ecological conservation and restoration strategies were used in each plot. In the construction process, technologies related to rainwater utilization of green building and sponge city should be applied, such as permeable pavement, roof rainwater utilization, concave green space, solar energy utilization, etc. While building, it can also create a good landscape effect, making the building a part of nature and ecology, rather than environmental vandals (Figure 6).

\subsubsection{Overall Planning Layout}

According to the upper planning requirements and the current situation of the base, the base is divided into commercial and residential mixed area, commercial area, cultural audio-visual area and public green area. Some buildings of the factory were demolished, and the wharf area of the factory adjacent to the Yangtze River was converted into a riverside park to provide recreational viewing area for surrounding citizens. The old factory building in the southwest is transformed into an exhibition hall and a ship Culture Museum is built to display the shipbuilding culture of Jinling Shipyard. The large volume of factory buildings are transformed into commercial rooms, which are used for cultural, audio-visual

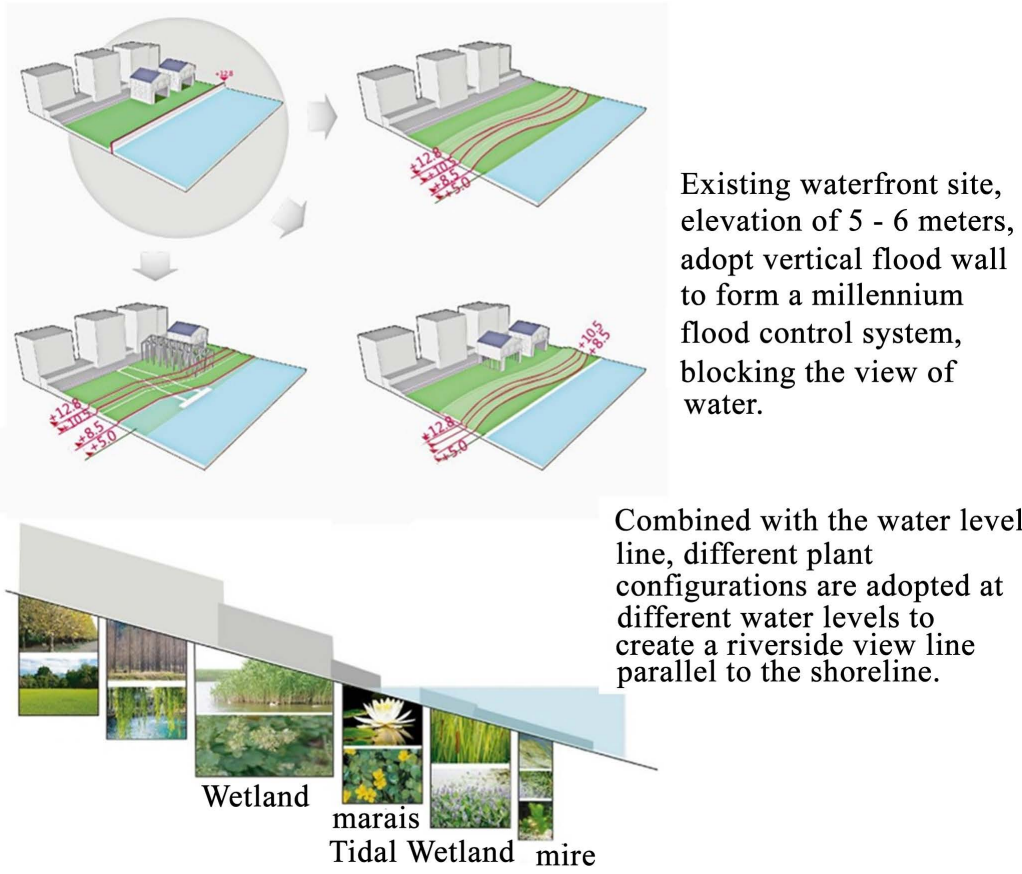

Figure 5. Waterfront shoreline restoration concept map. 
and innovative offices. The east side is partially inhabited. The whole base carries out the planning and design of "small blocks, dense road network". At the same time, it combines landscape corridors and public green space with open space to create a slow traffic system. It is hoped that by replicating people's most comfortable walking scale, it will bring comfortable slow walking life to citizens (Figure 7).
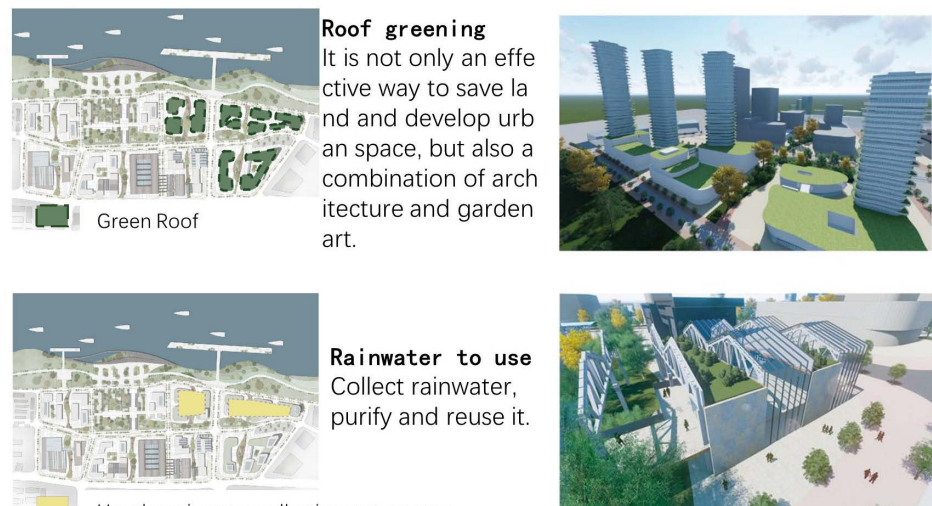

Rainwater to use

Collect rainwater purify and reuse it.

Use the rainwater collection system area.
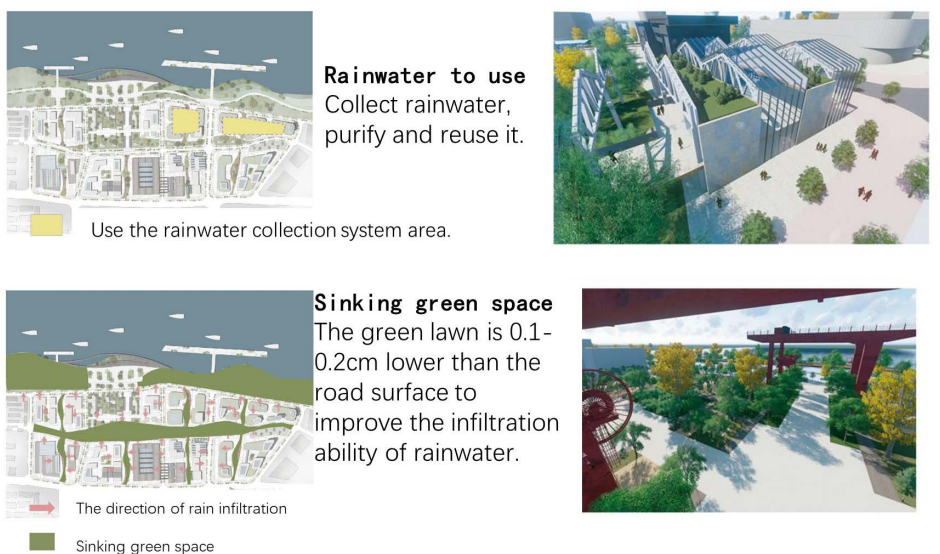

Figure 6. Concept map of rainwater utilization in the site.
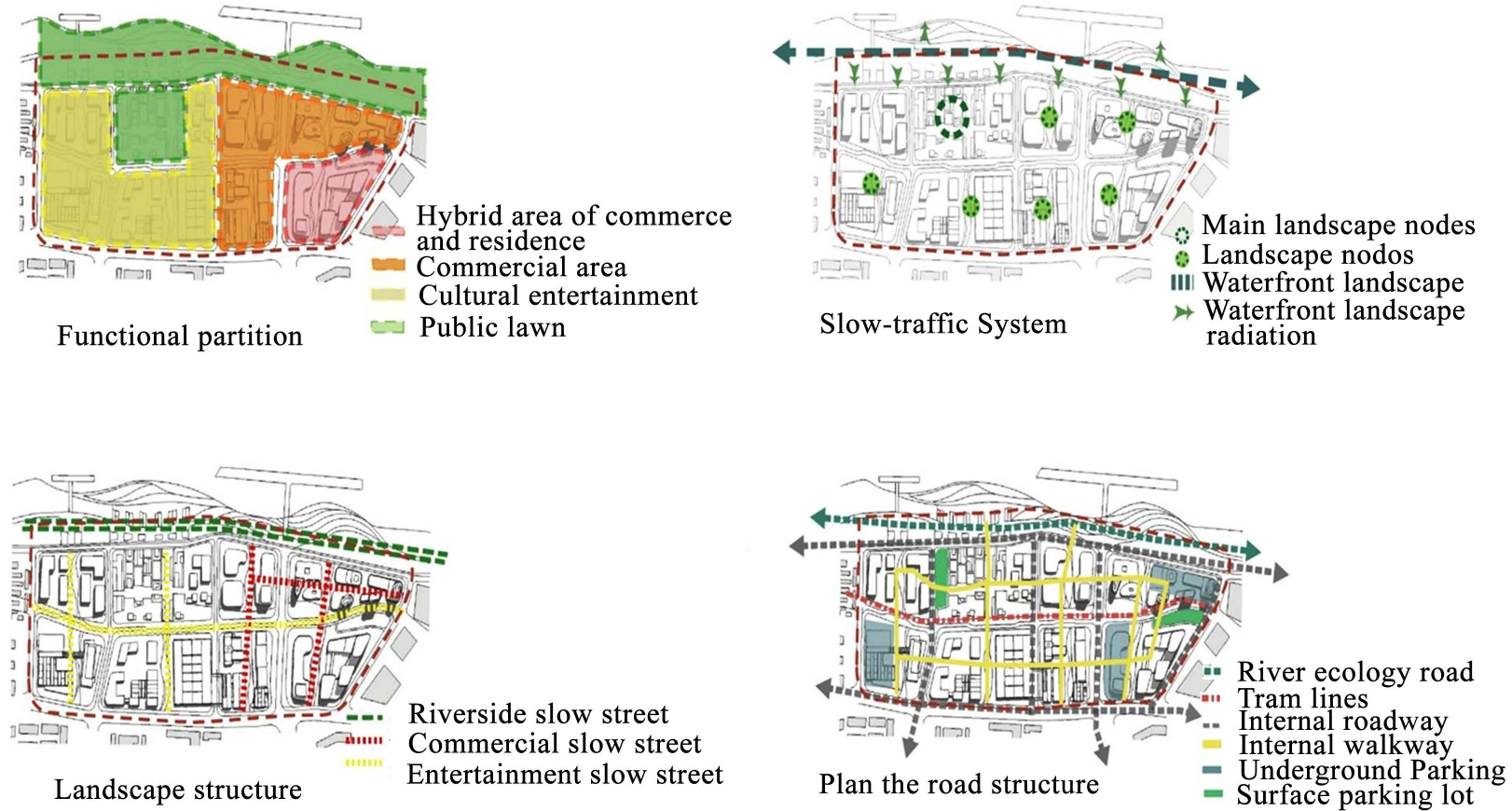

Figure 7. Analysis diagram. 


\section{Conclusion}

This paper starts with the perspective presented in the current urban renewal, and links the value brought by the industrial heritage itself; The organic renewal and cultural remodeling of industrial heritage were discussed and studied, and the industrial heritage was paid attention to in the process of urban repair and ecological restoration, so as to provide support for the renewal and protection of industrial heritage. And through the interpretation of relevant successful cases, combined with the demands of the development of Nanjing city as a whole and the construction of riverside area, curtain Jinling shipyard in Nanjing area as the research object, from the perspective of urban functions update and ecological restoration planning strategies and suggestions, deep research bases itself important industrial cultural connotation, to explore the effective transformation and redevelopment of urban space function.

\section{Conflicts of Interest}

The author declares no conflicts of interest regarding the publication of this paper.

\section{References}

Bao, Z. Y., \& Chen, B. (2004). Study on Revegetation during Ecological Restoration of Industrial Wasteland. Journal of Soil and Water Conservation, No. 3, 160-163, 199.

Cheng, L. (2014). Ecological Restoration and Landscape Regeneration of Industrial Wasteland. Northwest A \& F University.

France, R. L. (2010). Handbook of Regenerative Landscape Design. Taylor and Francis, CRC Press.

Gan, C. H., \& Wang, Q. (2018). Changes in China's Industrial Structure since the Reform and Opening-Up. Retrospect and Prospect, Research on Economics and Management, 39, 3-14.

He, W. (2004). Study of Post-Industrial Landscape. Tsinghua University.

Li, L. L. (2002). De-Industrialization and Development of Industrial Heritage Tourism: The Actual Process and Development Model of Ruhr in Germany. World Regional Studies, No. 3, 57-65.

Lin, C., \& Liu, X. Y. (2019). Application of Sponge City Concept in Urban River Treatment. Water Resources Development Research, 19, 57-63.

Merkel, J. (2007). Urban American Landscape. Architectural Design, 77, 36-47.

Niall, K. (2003). Manufactured Sites: Rethinking the Post-Industrial Landscape. Taylor and Francis.

Robinson, K., \& Wang, H. H. (2003). Exploring Urban Ecosystems in the Ruhr Region of Germany: Implementation Strategies. Urban Planning International, No. 6, 3-25.

Rong, Y. F., \& Cai, H. G. (2019). Research on the Renewal of Industrial Heritage Historical Area Based on "Urban Double Repair"-Taking the Old Area of Fuzhou Mawei Shipyard as an Example. Protection and Management, 4, 28-31.

Shan, J. X. (2007). Attention to Emerging Cultural Heritage-Protection of Industrial Heritage. Beijing Planning Review, 113, 11-14. 
Shi, W. H., Chen, J. G., \& Chen, S. (2017). Underground Utility Tunnel Planning Formulation and Relationship Coordination. Planners, 33, 123-128.

Wang, J. G., \& Rong, J. Q. (2001). Regeneration and Redevelopment of Historic Industrial Buildings and Sites. World Architecture, No. 6, 17-22.

Wang, X. R., \& Ren, J. Y. (2003). From Industrial Wasteland to Green Park. Chinese Landscape Architecture, No. 3, 11-18.

Wang, Y. F. (2017) Thinking on Industrial Heritage Protection and Utilization from the Perspective of Regional Network. Rational Planning for Sustainable Development-2017 China Annual National Planning Conference (09 Urban Cultural Heritage Protection), No. 9, 13.

Weilacher, U. (1999). Between Landscape Architecture and Land Art. Springer Verlag.

Wu, X. L. (2002). Main Characters and Experience of British Industrial Tourism. World Regional Studies, No. 4, 73-79.

Yang, Z. M. (2017). The Development Trend of Urban Landscaping in China. Xiandai Horticulture, No. 9, 90-92.

Zhang, J. Z. et al. (2021). The Overview of the Conservation and Renewal of the Industrial Belgian Heritage as a Vector for Cultural Regeneration. Information, 12, 27-27.

Zhang, L. (2018). Renewal and Exploration of the Old City Fringe from the Perspective of Urban Double Construction. Sharing and Quality-2018 China Annual National Planning Conference (02 Urban Renewal), No. 2, 16.

Zhuang, J. D. (2004). A Study on the Reuse of Old Industrial Buildings. Tsinghua University. 